\title{
Shell Growth Performance of Hatchery Produced Pinctada margaritifera: Family Effect and Relation with Cultured Pearl Weight
}

\section{Chin-Long KY* and Gilles LE MOULLAC}

Ifremer, UMR 241 Ecosystèmes Insulaires Oceaniens (EIO), Labex Corail, Centre du Pacifique, BP 49, 98719 Taravao, Tahiti, French Polynesia

\begin{abstract}
Size is the most important and valuable quality trait of cultured pearls produced by the black-lipped pearl oyster, Pinctada margaritifera. In French Polynesia, several breeding programmes have been started that aim to improve this size trait, which is highly related to shell growth rate in both recipient and donor oysters. Shell growth rate dictates the time of grafting, size of implanted nuclei and bio-mineralisation potential of the mantle and pearl sac. We assessed shell growth rate through routine digital shell biometric analysis on 22 hatchery families produced between 2005 and 2008. These included full-sib families and half-sib families derived from polyandry (one dam crossed with two or more sires). Results showed that: 1) a significant family effect was recorded for growth performance, analysed according to the Von Bertalanffy model, 2) a significant male effect was observed for some of the half-sib families and 3) a relationship was found between the shell growth performances of five families randomly selected and used as graft donors in a grafting experiment and the final weight of the cultured pearls produced. These results have important implications for the breeding of pearl oysters with high growth capacities: it may be possible to select oyster lines for the potential to produce large pearls using shell equivalent diameter estimated by the digital method as a selection criterion.
\end{abstract}

Keywords: Pinctada margaritifera; Pearl oyster; Hatchery-produced families; Growth performance; Shell diameter; Cultured pearl size

\section{Introduction}

The black-lip pearl oyster Pinctada margaritifera is a widespread species, occurring across the Indian and Pacific Oceans and in the eastern Mediterranean Sea. It also has a wide latitudinal range, from $30^{\circ} \mathrm{N}$ to $28^{\circ} \mathrm{S}$, reaching its greatest abundance in the lagoons of French Polynesia [1]. It typically inhabits oligotrophic waters of low turbidity, attaching itself by byssal threads to coral reef substrates [2,3]. Today, the black pearl industry remains the second most important economic activity in French Polynesia, after tourism, and is the largest export industry (7.8 billion CFP Francs in 2013). By 2013, this industry had developed on 25 islands and atolls, with 517 pearl farms located across three archipelagos: Tuamotu (398 farms), Gambier (79 farms), and Society (40 farms) [4]. However, this industry has been declining since 2001 and is now facing a critical situation due to a combination of several economic factors: slowdown of the world economy, overproduction of pearls, and poor average pearl quality. It is estimated that only $5 \%$ of harvested pearls can be classed as grade A quality according to local regulatory standards [5]. In this context, there is a need to take measures that will enhance pearl quality, thus increasing the proportion of high value pearls.

One of the most important traits determining the commercial value of pearls is their weight (for equivalent grade quality); with the heaviest pearls generally commanding the highest prices. Weight of cultured P. margaritifera pearls typically ranges from $0.75 \mathrm{~g}$ to $14.48 \mathrm{~g}$. Heavier specimens are usually issued from a surgreffe operation: insertion of a new nucleus following pearl harvest [6,7]. Shell and cultured pearl formation result from the bio-mineralization activities of two distinct tissues in a grafted pearl oyster: the mantle of the recipient oyster and the pearl sac built from graft tissues from the donor [5]. The pearl weight finally attained depends on several factors, including whether or not the donor oyster originated from the wild [8] or from a hatchery-produced family $[9,10]$. Some studies have shown phenotypic correlations between pearl weight and recipient oyster shell traits, e.g., for Pinctada fucata [11-13]. Wada and Komaru [14] studied the phenotypic correlation between pearl size (and thus weight) and recipient shell valve weight in P. fucata martensii and found a positive relationship whereby oysters with heavier valves produced larger pearls. Another study, on Hyriopsis cumingii, showed that improving body length or weight in culture of this species indirectly led to improved pearl weight and size [15]. Jerry et al. [16], revealed genotype by environment $\left(G^{*} \mathrm{E}\right)$ interaction for pearl weight in Pinctada maxima reared at two commercial grow-out locations. Indeed, environmental influences have been shown to be important factors to consider in P. margaritifera aquaculture $[17,18]$.

The most important environmental parameters influencing bivalve growth are temperature and food availability [19-21], which is typical of many aquatic invertebrates. The influence of food availability on $P$. margaritifera in French Polynesia was demonstrated by Pouvreau et al. $[22,23]$. Growth studies are of interest for pearl farming, since growth represents the integrated response of the organism's entire physiological activity. Shell growth rates can provide precious information on pearl growth in $P$. margaritifera since shell increment and deposition of nacreous matter on the implanted nucleus are strongly correlated [24]. Pouvreau \& Prasil [23] also demonstrated geographic variability in P. margaritifera growth among different sites in French Polynesia. This bivalve grows rapidly up to a phase of its development where size increase levels off and then falls to zero. On the basis of growth modelling (Von Bertalanffy model [25]), the time required for a pearl oyster to reach the size necessary to be grafted as a recipient (height $=100$

*Corresponding author: Chin-Long KY, Ifremer, UMR 241 Ecosystèmes Insulaires Oceaniens (EIO), Labex Corail, Centre du Pacifique, BP 49, 98719 Taravao, Tahiti, French Polynesia, Tel: 00 (689) 405460 09; Fax: 00 (689) 405460 99; E-mail: chinky@ifremer.fr

Received March 03, 2016; Accepted May 12, 2017; Published May 15, 2017

Citation: Chin-Long KY, Gilles LE MOULLAC (2017) Shell Growth Performance of Hatchery Produced Pinctada margaritifera: Family Effect and Relation with Cultured Pearl Weight. J Aquac Res Development 8: 480. doi: 10.4172/2155-9546.1000480

Copyright: (c) 2017 Chin-Long KY, et al. This is an open-access article distributed under the terms of the Creative Commons Attribution License, which permits unrestricted use, distribution, and reproduction in any medium, provided the original author and source are credited. 
$\mathrm{mm}$ ) depends on pearl farming site as, in French Polynesia, the annual growth rate in shell size varies from $19.7 \mathrm{~mm}$ to $31.8 \mathrm{~mm}$ year ${ }^{-1}$ [23].

Selective breeding programmes have been shown to be effective for improving performance of many aquaculture species. A selective breeding programme on $P$. margaritifera is currently underway at Ifremer (French Research Institute for the Exploitation of the Sea) in French Polynesia, with the main goal of establishing pearl oyster lines selected for growth. The main objective of the present study was to analyse the growth performance of $22 \mathrm{G} 1$ families by routine digital growth measurements on their shells and then assess the impact of growth and family effects on pearl weight through a grafting experiment using donor oysters from some of these families. This study will help the development of breeding programmes to produce oyster lines that will enhance cultured pearl weight.

\section{Materials and Methods}

\section{Breeding and rearing of $P$. margaritifera}

Twenty-two families (full and half-sib) were produced in the Ifremer hatchery in Vairao (Tahiti, French Polynesia) between 2005 and 2008 by spawning non-selected females $(\mathrm{N}=14)$ and males $(\mathrm{N}=22)$ from wild broodstock (Table 1). Spawning was triggered by thermal shock [25] whereby the pearl oysters were placed in cooled seawater at $20^{\circ} \mathrm{C}$ for one night before being plunged into seawater at $31^{\circ} \mathrm{C}$ to $32^{\circ} \mathrm{C}$. Immediately spawning started, the male and female oysters were placed in separate containers for gamete collection. To minimize the risk of contamination, oocytes were thoroughly rinsed out of the mantle cavities of the spawning females. The oocytes were fertilized with the spermatozoa of males selected on the basis of sperm motility. Rearing was conducted in a static system without antibiotics. The larval

\begin{tabular}{|c|c|c|c|c|c|c|}
\hline \multicolumn{2}{|c|}{ G1 Families } & \multicolumn{2}{c|}{ Crosses } & \multicolumn{3}{c|}{ Growth parameters } \\
\hline Name & $\begin{array}{c}\text { Age } \\
\text { (year) }\end{array}$ & Female & Male & k & Eq. . & $\mathbf{R}^{2}$ \\
\hline O58 & 3.80 & $\mathrm{x}$ & $\mathrm{y}$ & 0.61 & 11.46 & 0.62 \\
\hline F610 & 3.12 & K43 & O24 & 0.64 & 10.65 & 0.97 \\
\hline F612 & 3.12 & I21 & O40 & 0.90 & 8.96 & 0.89 \\
\hline F613 & 3.02 & FA7 & FA1 & 0.35 & 14.62 & 0.94 \\
\hline F615 & 3.02 & EQ1 & EZ8 & 0.43 & 12.43 & 0.94 \\
\hline F618 & 2.53 & ED2 & FF8 & 0.33 & 15.41 & 0.88 \\
\hline F617 & 2.53 & ED2 & GC1 & 0.34 & 12.55 & 0.80 \\
\hline F616 & 2.53 & ED2 & BL3 & 0.43 & 9.52 & 0.98 \\
\hline F620 & 2.47 & C8 & ED4 & 0.25 & 18.92 & 0.82 \\
\hline F622 & 2.47 & C8 & B99 & 0.40 & 12.57 & 0.94 \\
\hline F621 & 2.47 & C8 & GV8 & 0.77 & 11.42 & 0.94 \\
\hline F619 & 2.47 & C8 & B92 & 0.36 & 11.02 & 0.91 \\
\hline F701 & 2.30 & 279 & 367 & 0.82 & 8.61 & 0.85 \\
\hline F702 & 2.28 & O48 & W2 & 0.47 & 12.22 & 0.91 \\
\hline F703 & 2.28 & O48 & 268 & 0.51 & 11.16 & 0.90 \\
\hline F704 & 2.28 & 237 & 251 & 1.05 & 7.34 & 0.90 \\
\hline F732 & 1.51 & BS7 & AY8 & 0.27 & 17.59 & 0.97 \\
\hline F733 & 1.43 & AV6 & GE9 & 0.23 & 26.07 & 1.00 \\
\hline F801 & 1.32 & BX2 & CD9 & 0.24 & 21.39 & 1.00 \\
\hline F806 & 1.32 & AS8 & 350 & 0.21 & 22.04 & 0.96 \\
\hline F805 & 1.32 & AS8 & 270 & 0.21 & 21.41 & 0.99 \\
\hline F804 & 1.32 & AS8 & CC2 & 0.30 & 18.76 & 0.98 \\
\hline
\end{tabular}

Table 1: Stocklist of the 22 first generation (G1) families of $P$. margaritifera produced in the hatchery from wild broodstocks. Crosses shown in boxes used the same female crossed with several males (4 polyandry matings that produced half-sib families). Growth parameters are: 1) the $\mathrm{k}$ constants and 2) equivalent shell diameters eq

$\mathrm{D}$, following the Von Bertalanffy bivalve growth model. $\mathrm{R}^{2}$ value corresponds to the relationship between shell height measured by calliper and eq. $D$. and juvenile rearing procedures used were as described in [26]. After 3 months, the young spat was placed in plastic trays (Aquapurse') and reared in Vairao lagoon, where they were suspended on long lines. The trays were maintained at a depth ranging between 6 and 10 metres and cleaned every 3 months.

\section{Digital shell growth analysis of the $P$. margaritifera families}

A sample of pearl oysters $(\mathrm{N}=478)$ in the size range size $0.7-10.2$ $\mathrm{cm}$ shell height was used to validate the digital shell growth analysis method described above. Size of all pearl oysters was measured every four months. The oysters were spread out over a cream-coloured PVC plate, and pictures were taken using a digital camera (Olympus $\mu 790$ SW, 7.1 megapixels) fixed on a base at 1 metre above the oysters. This method made it possible to simultaneously measure a hundred young oysters or ten large ones. The digital biometry was first compared with the classic measurement method for shell height, using a calliper on a large range of oyster sizes. The calibration of pictures was made using black circles of $10 \mathrm{~cm}$ diameter. Pictures were first treated with Photoshop ( ${ }^{\oplus}$ Adobe Systems CS3, version 10.0). ImageJ software $\left({ }^{\circ}\right.$ Broken Symmetry, version 1.4.3.67) was then used to obtain the area of the oysters, which allowed the calculation of the equivalent diameter and the major and minor axes of the ellipse of adjustment. Correlations were first tested between the height data collected with callipers and the digitally measured parameters: area and major and minor axes. The growth of pearl oysters was described using the equivalent diameter (eqD). For each of the 22 hatchery-produced families, 50 individuals were measured during cleaning process, every 3 months.

\section{Experimental grafting procedure}

In order to evaluate the link between growth of donor families and the corresponding harvested pearls, a graft experiment was designed. As the grafting operation, itself may introduce factors that influence cultured pearl quality [27], all grafts were undertaken by a single professional technician to minimise variability in technique. The donor oysters used were from five families (O58, F612, F613, F615 and F622), randomly selected from the 22 hatchery-produced families. A total of 50 donors ( 10 per family) were used to perform 500 grafts (10 grafts per donor) over a 4-day period (28-31 May 2008) in Mangareva (Gambier Archipelago, French Polynesia) under the same conditions as used for a commercial graft (see [28] for a description of this method). All recipient pearl oysters came hatchery-produced oysters from a same family (other than the 22 studied families for growth) with mean ( \pm SE) antero-posterior measurement of $75.38( \pm 5.64) \mathrm{mm}$ and dorso-ventral measurement of $80.08( \pm 7.72) \mathrm{mm}$. They were selected based on good visible health status (colour of the visceral mass and gills), shell size appearance, and muscle resistance when the shells were pried open for grafting. Each recipient was grafted using a $2.0 \mathrm{BU}$ nucleus $(6.06 \mathrm{~mm}$ diameter; Nucleus Bio, Hyakusyo Co. Japan). The grafted pearl oysters were reared in kangaroo pocket baskets in Mangareva lagoon, following standard commercial practices until harvest of the pearls 14 months later (15-17 July 2009).

\section{Cultured pearl weight measurement}

After 14 months of culture, the cultured pearls were harvested and placed in a compartmented box that allowed traceability between the pearls and the corresponding donor oysters. Some keshi (small irregular shaped nacreous but non-nucleated pearls that form during the culture period after nuclei have been rejected) were also harvested, but not graded. Cultured pearls were then cleaned by ultrasonication in soapy water (hand washing) with a LEO 801 laboratory cleaner (2 L capacity, $80 \mathrm{~W}, 46 \mathrm{kHz}$ ) according to Ky et al. [9]. Each pearl was 
then individually weighed with an Ohaus Explorer EP214D analytical balance (0.1 mg sensitivity).

\section{Statistical analysis}

Data from shell growth were modelled according to the nonlinear regression of Von Bertalanffy [29], which has been widely used for bivalve growth [25], using XLStat 2008.6.08 software. The Von Bertalanffy equation is: $H=H_{\infty}\left[1-e^{-k(t 1-t 0)}\right]$, where $\mathrm{H}$ is the height in millimetres at time $t, \mathrm{H}_{\infty}$ is the asymptotic height in millimetres, $\mathrm{t}$ is the age in years and $\mathrm{k}$ is the rate at which the asymptotic value is approached in year ${ }^{-1} . \mathrm{H}$ and $\mathrm{H}_{\infty}$ were replaced by eqD and eqD $\mathrm{es}_{\infty}$ described in the above "digital shell growth analysis" section. The shell heights are presented on the figures with vertical bars representing the 95\% confidence intervals. One-way analysis of variance (ANOVA) was used to test for differences for pearl weights among the families. If the overall F-test was significant, Tukey multiple comparisons were performed among all pairs of families. Correlations between the shell growth donor $\mathrm{k}$ value and pearl size were tested using the critical value table for Pearson's correlation coefficient at the 5\% alpha level.

\section{Results and Discussion}

\section{Family effect on shell growth performance}

The equivalent diameter (eqD value) of oyster shells was significantly correlated with the height measured among the 478 pearl oysters in our study $(\mathrm{r}=0.994)$. This made it possible to monitor shell growth performance of the 22 hatchery families using the digital method. The constant values $\left(\mathrm{k}\right.$ and $\mathrm{eqD} \mathrm{D}_{\infty}$ ) of the non-linear regressions of the Von Bertalanffy model are presented in Table 1 and the corresponding modelled growth in Figure 1. Great variability was observed for growth potential among the 22 families studied. Comparison between pairs of families of the same age reared simultaneously in the same location and conditions (F616-F621 and F732-F733) show significant differences in shell growth capacity (Figure 1). The growth difference between families F616 and F621, measured over one year (from 1.5 to 2.5 years old), was 35 to $44 \%$ in favour of family F621. This corresponds to growth constants of $\mathrm{k}=0.43$ and 0.77 for F616 and F621, respectively (Table 1). In contrast, between the younger families F732 and F733, in which growth was monitored from the age of 0.84 to nearly 1.5 years old, the growth differences were $2 \%$ to $20 \%$, respectively at these measurement

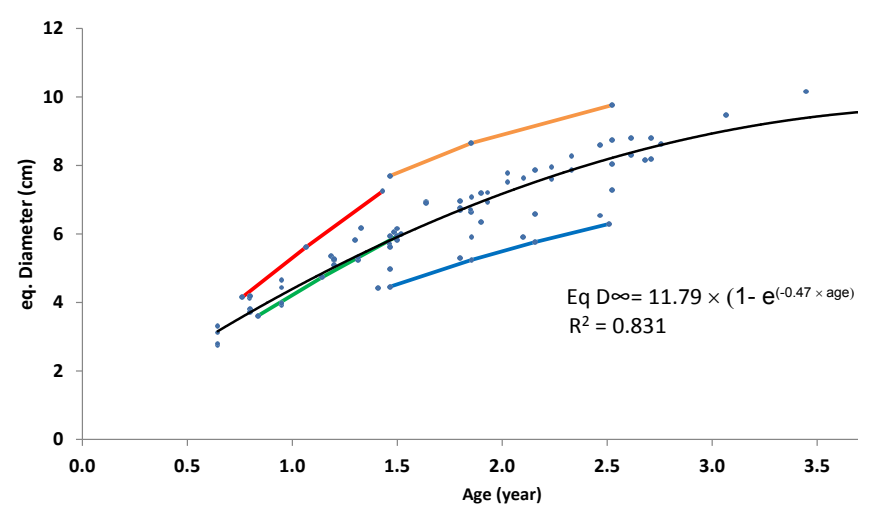

Figure 1: Establishment of a growth model for 22hatchery-produced families of $P$. margaritifera. The graph shows the relationship between their shell equivalent diameters $(\mathrm{cm})$ and ages (years) all families combined $(50<\mathrm{N}<250)$. Families F616 (blue), F621 (orange), F733 (red) and F732 (green) shell growth capacities are highlighted. The Von Bertalanffy non-liner regression model is shown. times. These growth differences correspond to eqD values of 17.6 and 26.07 for F732 and F733 families, respectively (Table 1).

In general, shell growth rate is directly correlated with the biological age of an individual P. margaritifera pearl oyster. Growth rate (in terms of shell height) is rapid until the third year, and then decreases [23]. The specificity of this growth pattern has already been reported in other species in the Pinctada genus [1,30,31]. The decrease in growth rate in relation to age is highly correlated with the metabolic cost associated with sexual maturation, as the energy previously allocated to growth performance is instead diverted mainly to sexual maturation and reproductive effort [32]. The bivalves nevertheless attain their genetically-determined species-specific maximal size. Our results suggest there is a family effect for growth performance, which is particularly visible in the F616-F621 and F732-F733 pairs that were produced in the same period and therefore reared in identical environmental conditions. The growth parameters proposed by the Von Bertalanffy non-linear regression model may be used as performance descriptors. The parameters in our study should be considered as preliminary ones, however, because the growth of the families did not cover the entire life of the pearl oysters, these individuals were relatively young, and the growth asymptote was not reached. The observed differences between the growth of the families could result from three types of growth dynamic: 1$)$ the same Eq $D \infty=11.79 \times\left(1-\mathrm{e}^{(-0.47 \times \text { age })}\right)$ but different $\mathrm{k}$ values; 2$)$ the same $\mathrm{k}$ value, but different $\mathrm{Eq} \mathrm{D} \infty=11.79 \mathrm{x}$ (1$\left.\mathrm{e}^{(-0.47 \times \text { age })}\right)$ or 3$)$ different $\mathrm{k}$ and eqD $\mathrm{D}_{\infty}$ values.

Significant half-sib family effects were found within the four polyandry matings (Table 1). Comparing the half-sib families F616, F617 and F618, the male FF8 (sire of the F618 half-sib family) offers a growth advantage of $15 \%$ and $24 \%$ on average over families F617 and F616, respectively (Figure 2a). For the half-sibs F619, F620, F621 and F622 families, the male GV8 (sire of the F621 half-sib family) offers a growth advantage of 36,17 and $19 \%$ on average in comparison to families F619, F620 and F622, respectively (Figure 2b). In contrast, the F702-F703 and F805-F806 pairs were not significantly different in growth performance (Figures $2 \mathrm{c}$ and $2 \mathrm{~d}$ ).

For the four half-sib combinations resulting from the polyandry mating design (a single female crossed with two to four different males), the result showed that the growth capacity could be determined by the male, resulting in a side effect, especially for the F618 and F621 families. This finding complements results showing half-sib family effect in an earlier study on spat growth performance [33], where only a maternal effect was suggested at this earlier life stage. The results obtained here with the family pairs F702-F703 and F805-F806, revealed no male effects, indicating that in some cases sire confer no growth benefit to their progenies. Selection of males remains an interesting prospect for genetic programs, as $P$. margaritifera is a protandric species and this therefore represents a means to save time.

\section{Pearl weight and its relationship with shell growth perfor- mance of the families used as donors}

After 14 months of culture, the 366 harvested pearls from the five randomly selected families used as donors (FO58, F612, F613, F615 and F622) showed an average weight of $1.16 \pm 0.36 \mathrm{~g}$, with a minimummaximum range of $0.40 \mathrm{~g}$ to $2.72 \mathrm{~g}$. A highly significant family effect was detected for pearl weight $(\mathrm{F}=12.00, p<0.0001)$. Tukey multiple comparisons showed that family O58 was significantly different from the other four, but that these latter were not significantly different from one another. A relationship was established between the k parameter of growth model of the five families (Table 1) and the weight of the corresponding pearls (Figure 3 ). The nonlinear relationship was significant $(p<0.05, \mathrm{r}=0.870, \mathrm{ddl}=3)$. 

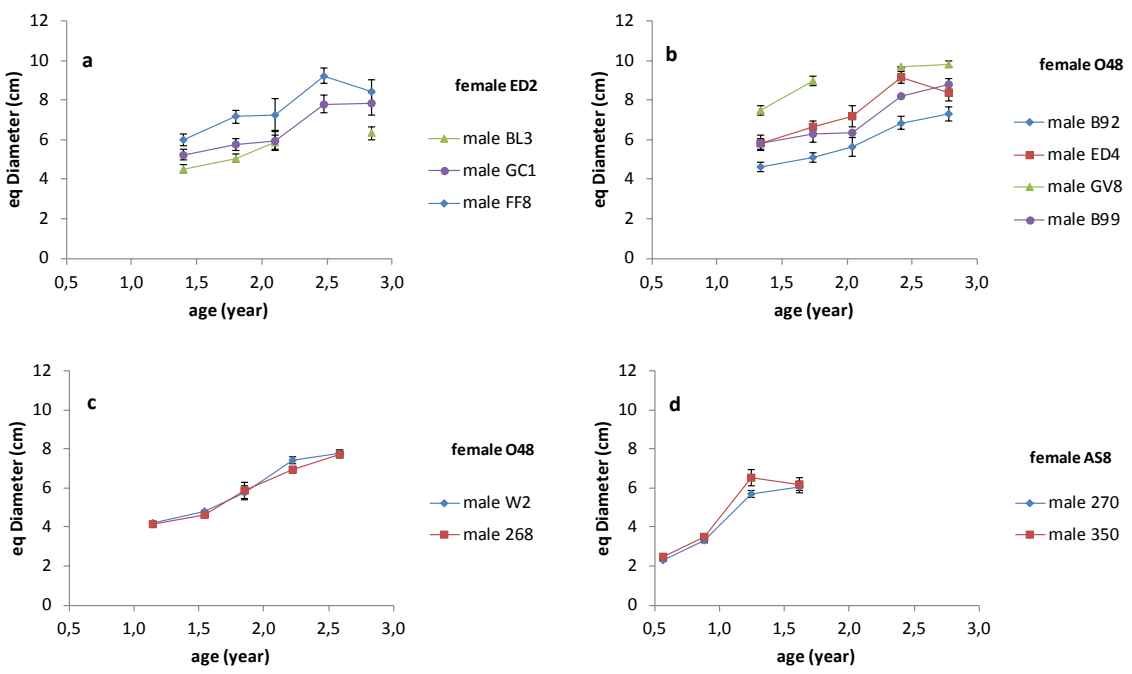

Figure 2: Growth of the 11 P. margaritifera half-sib families (corresponding to four polyandrous matings, refer Table 1); (a) families F616, F617 and F618 (b) families F619, F620, F621 and F622 (c) families F702 and F703 (d)families F805 and F806; the pearl oyster shell equivalent diameter (eq. Diameter) is expressed in cm and oyster age in years (means are presented with vertical bars representing $95 \%$ confidence intervals with $50<\mathrm{N}<250$ ).

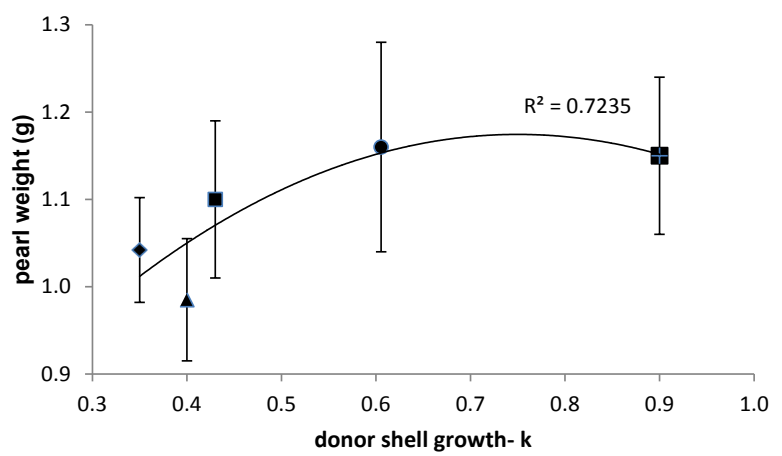

Figure 3: Correlations between the cultured pearl weight (in $\mathrm{g}$ ) and donor oyster $\mathrm{k}$ values, following the Von Bertalanffy bivalve growth model (diamond: F613, triangle: F622, square: F615, circle: O58, cross: F612).

Pearl weight is an important commercial trait. Generally, the greater the nacre deposition rate (as measured by nacre weight) for oysters implanted with nuclei of the same size, the heavier (and more valuable) the resulting pearl should be, all other quality traits being equal. Consequently, there may be advantages to the industry in using pearl oyster donors promoting rapid nacreous deposition. Our results clearly show a correlation between the k growth parameter and the weight of the harvested pearls. Pearl weight is mainly dependent on calcium metabolism in the pearl sac, the epithelial tissue around the pearl epithelium derived from the mantle cells of the donor [34]. Although research on factors influencing the weight of pearls is limited, influence of donor oysters on pearl weight has been suggested [35]. Indeed, cells of donor origin appear to persist in the pearl sac. When genotyping the pearl sac and the corresponding recipient oysters with anonymous nuclear markers, alleles from the donor oyster are still detected in the pearl sac at pearl harvest [36]. The persistence of donor oyster cells and their activity in the pearl sac supports our result concerning the relationship between $\mathrm{k}$ values of donor pearl oysters and pearl weight obtained with these donors. Nevertheless, further studies should be conducted, particularly on the role of the recipient oyster, as its physiological condition and activity in interaction with the environment probably also strongly influence the potential for calcium metabolism in the pearl sac epithelium.
Care should be taken concerning possible relationships between rapid nacre deposition and other pearl quality traits, such as colour or calcite pearl formation. For example, Snow et al. [37] hypothesized that pearls with a smooth surface and brilliant lustre are produced when consistent and regular crystal formation occurs, which is not compatible with a high nacre deposition rate. Ky et al. [9] showed a strong family effect on pearl weight, but a significant effect of pearl colour was also detected, as well as a significant family* colour interaction. This indicates that potential relationships between weight and colour may vary among families. Selection for one trait may thus lead to indirect selection on others. As with any genetic improvement method, a better understanding of genetic correlations is necessary to avoid inadvertent selection for or against non-target traits.

\section{Conclusion}

Our study demonstrates that the potential exists to improve pearl growth rates in $P$. margaritifera. Selection of hatchery-produced $P$. margaritifera donors with high growth performances, and thus high potential for nacre deposition, could be used to increase cultured pearl weight, size and nacre deposition rate. Such family-based selection could be assisted by molecular tools such as those revealed in initial gene expression studies as potential biomarkers for pearl growth, e.g., Pif, Aspein and Pearlin gene families [38]. This genetic selection, using the routine digital method, could also be incorporated in hatchery-reared spat, which are now used for commercial production in $P$. margartifera in French Polynesia $[39,40]$. Overall, to improve cultured pearl size via selection, a multi-trait approach should be used, integrating several oyster lines, considering the key role played by recipients, and taking into account quantitative genetic control, environmental effects and associated correlations. In an effort to identify the genetic basis and molecular mechanisms underlying shell growth in P. margaritifera and provide fundamental information to assist selective breeding of superior pearl oyster lines with high performance growth potential, differentially expressed genes could be identified among the different spat shell size variants at the transcriptome level by RNA sequencing. Such integrative research should improve our understanding of the processes implicated in animal growth performance but also in the cultured pearl traits important for the P. margaritifera industry. 
Citation: Chin-Long KY, Gilles LE MOULLAC (2017) Shell Growth Performance of Hatchery Produced Pinctada margaritifera: Family Effect and Relation with Cultured Pearl Weight. J Aquac Res Development 8: 480. doi: 10.4172/2155-9546.1000480

Page 5 of 6

\section{Acknowledgements}

The authors are grateful to the team at Pearl Farm and support provided by the Direction des Ressources Marines et Minières (Mangareva Island, Gambie Archipelago, French Polynesia) for the experimental grafts and maintenance of the oyster cultures. The authors would also like to thank Mayalen Maihota, Jacques Moriceau, Manaarii Sham Koua, Roger Tetumu and Vincent Vanaa for their technical support with the biological material used in the present study that was produced between 2005 and 2008 .

\section{References}

1. Gervis MH, Sims NA (1992) The biology and culture of pearl oysters (Bivalvia: Pterridae). ICLARM Stud 21: 49.

2. Pouvreau S, Jonquières G, Buestel D (2000) Filtration by the pearl oyster Pinctada margaritifera, under conditions of low seston load and small particle size in a tropical lagoon habitat. Aquaculture 176: 295-314.

3. Yukihira H, Lucas JS, Klump DW (2000) Comparative effects of temperature on suspension feeding and energy budgets of the pearl oysters Pinctada margaritifera and P. maxima. Mar Ecol Prog Ser 195: 179-188.

4. Talvard C (2015) In: Points Forts de la Polynésie Française. Institut de la Statistique en Polynésie Française, Papeete, Polynésie Française.

5. Ellis S, Haws M (1999) Producing pearls using the black-lip pearl oyster. Center for Tropical and Sub-tropical Aquaculture Publications, Hawaii.

6. Demmer J, Cabral P, Ky CL (2016) Comparison of harvested rate and nacre deposition parameters between cultured pearls issued from initial graft and second nucleus insertion in $P$. margaritifera. Aquaculture Research 47 3297-3306.

7. Ky CL, Demmer J, Sham Koua M, Cabral P (2015) Development of cultured pearl circles and shape after initial graft and second nucleus insertion in the black-lipped pearl oyster Pinctada margaritifera. Journal of Shellfish Research 34: 319-328.

8. Tayale A, Gueguen Y, Treguier C, Le Grand J, Cochennec-Laureau N, et al (2012) Evidence of donor effect on cultured pearl quality from a duplicated grafting experiment on Pinctada margaritifera using wild donors. Aquatic Living Resource 25: 269-280.

9. Ky CL, Blay C, Sham Koua M, Vanaa V, Lo C, et al. (2013) Family effect on cultured pearl quality in black-lipped pearl oyster Pinctada margaritifera and insights for genetic improvement. Aquatic Living Resources 26: 133-145.

10. Ky CL, Blay C, Sham Koua M, Lo C, Cabral P (2014a) Indirect improvement of pearl grade and shape in farmed Pinctada margaritifera by donor "oyster" selection for green pearls. Aquaculture 432: 154-162.

11. Wada KT (1984) Breeding study of the pearl oyster Pinctada fucata. Bull Natl Res Inst Aquaculture 6: 79-157.

12. Velayudan TS, Chellam A, Dharmaraj S, Victor ACC, Kasim HM (1996) Comparison of growth and shell attributes for four generations of pearl oyster Pinctada fucata (Gould) produced in the hatchery. Indian Journal of Fisheries 43: 69-77.

13. He M, Guan Y, Yuan T, Zhang H (2008) Realized heritability and response to selection for shell height in the pearl oyster Pinctada fucata (Gould). Aquaculture Research 39: 801-805.

14. Wada KT, Komaru A (1996) Color and weight of pearls produced by grafting the mantle tissue from a selected population for white shell color of the Japanese pearl oyster Pinctada fucata martensii (Dunker). Aquaculture 142: 25-32.

15. Jin W, Bai Z, Fu L, Zhang, G, Li J (2012) Genetic analysis of early growth traits of the triangle shell mussel, Hyriopsis cumingii, as an insight for potential genetic improvement to pearl quality and yield. Aquaculture International 20 927-933.

16. Jerry DR, Kvingedal R, Lind CE, Evans BS, Taylor JJU, et al. (2012) Donoroyster derived heritability estimates and the effect of genotype $\mathrm{x}$ environment interaction on the production of pearl quality traits in the silver-lip pearl oyster, Pinctada maxima. Aquaculture 338: 66-71.

17. Ky CL, Blay C, Aiho V, Cabral P, Le Moullac G, et al. (2017) Macrogeographical differences influenced by family-based expression on cultured pearl grade, shape and colour in the black-lip pearl oyster Pinctada margaritifera: A preliminary case study in French Polynesia. Aquaculture Research 48: 270-282.

18. Le Pabic L, Parrad P, Sham KM, Nakasai S, Saulnier D, et al. (2016) Culture site dependence on pearl size realization in Pinctada margaritifera in relation to recipient oyster growth and mantle graft bio-mineralization gene expression using the same donor phenotype. Estuarine, Coastal and Shelf Science 182 294-303.

19. Honkoop PJC, Beukema JJ (1997) Loss of body mass in winter in three intertidal bivalve species: An experimental and observational study of the interacting effects between water temperature, feeding time and feeding behaviour. J Exp Mar Biol Ecol 212: 277-297.

20. Pilditch CA, Grant J (1999) Effect of temperature fluctuations and food supply on the growth and metabolism of juvenile sea scallops (Placopecten magellanicus). Marine Biology 134: 235-248.

21. Marsden ID (2004) Laboratory and field experiments investigating the effects of reduced salinity and seston availability on growth of the little-neck clam Austrovenus stutchbury. Marine Ecology Progress Series 266: 157-171.

22. Pouvreau S, Tiapari J, Gangnery A, Lagarde F, Garnier M, et al. (2000) Growth of the black-lip pearl oyster, Pinctada margaritifera, in suspended culture under hydro-biological conditions of Takapoto lagoon (French Polynesia). Aquaculture 184: 133-154

23. Pouvreau S, Prasil V (2001) Growth of the black-lip pearl oyster, Pinctada margaritifera, at nine culture sites of French Polynesia: Synthesis of several sampling designs conducted between 1994 and 1999. Aquatic Living Resources 14: 155-163.

24. Coeroli M, Mizuno K (1985) Study of different factors having an influence upon the pearl production of the black lip pearl oyster. Proceedings of The Fifth International Coral Reef Congress 5: 551-556.

25. Hui B, Vonau V, Moriceau J, Tetumu R, Vanaa V, et al. (2011) Hatchery-scale trials using cryopreserved spermatozoa of black-lip pearl oyster (Pinctada margaritifera). Aquatic Living Resources 24: 219-223.

26. Vakily JM (1992) Determination and comparison of bivalve growth, with emphasis on Thailand and other tropical areas. ICLARM Tech Rep 36: 125.

27. Ky CL, Lau C, Sham Koua M, Lo C (2015) Growth performance comparison of Pinctada margaritifera juveniles produced by thermal shock or gonad scarification spawning procedures. Journal of Shellfish Research 34: 811-817.

28. Ky CL, Nakasai S, Molinari N, Devaux D (2015) Influence of grafter skill and season on cultured pearl shape, circles and rejects in Pinctada margaritifera aquaculture in Mangareva lagoon. Aquaculture 435: 361-370.

29. Ky CL, Molinari N, Moe E, Pommier S (2014b) Impact of season and grafter skill on nucleus retention and pearl oyster mortality rate in Pinctada margaritifera aquaculture. Aquaculture International 22: 1689-1701.

30. Von-Bertalanffy L (1938) A quantitative theory of organic growth (Inquiries on growth laws II). Hum Biol 10: 181-213.

31. Nalluchinnappan I, Sudhandra Dev D, Irulandi M, Jeyabaskaran Y (1982) Growth of pearl oyster Pinctada fucata (Gould) in cage culture at Kundugal channel, Gulf of Mannar. Indian J Mar Sci 11: 193-194.

32. Numaguchi K (1994) Growth and physiological condition of the Japanese pear oyster, Pinctada fucata martensii (Dunker, 1850) in Ohmura Bay, Japan. J Shellfish Res 13: 93-99.

33. Thompson RJ (1984) Production, reproductive effort, reproductive value and reproductive cost in a population of the blue mussel Mytilus edulis from a subartic environment. Mar Ecol Prog Ser 16: 249-257.

34. Ky CL, Blay C, Lo C (2015) Half-sib families' effect on cultured pearl quality traits in the black-lipped pearl oysters Pinctada margaritifera: testing for indirect benefits of polyandry and polygyny. Aquaculture International 24: 171-182.

35. Wada KT (1972) Relationship between calcium metabolism of pearl sac and pearl quality. Bull Natl Pearl Res Lab 16: 1949-2027.

36. McGinty EL, Evans BS, Taylor JUU, Jerry DR (2010) Xenografts and pear production in two pearl oyster species, $P$. maxima and $P$. margaritifera: Effect on pearl quality and a key to understanding genetic contribution. Aquaculture 302: $175-181$

37. Arnaud-Haond S, Goyard E, Vonau V, Herbaut C, Prou J, et al. (2007) Pearl formation: persistence of the graft during the entire process of biomineralization. Marine Biotechnology 9: 113-116.

38. Snow MR, Pring A, Self P, Losic D, Shapter J (2004) The origin of the color of pearls in iridescence from nano-composite structures of the nacre. Am Mineral 89: $1353-1358$. 
Citation: Chin-Long KY, Gilles LE MOULLAC (2017) Shell Growth Performance of Hatchery Produced Pinctada margaritifera: Family Effect and Relation with Cultured Pearl Weight. J Aquac Res Development 8: 480. doi: 10.4172/2155-9546.1000480

Page 6 of 6

39. Joubert C, Piquemal D, Marie B, Manchon L, Pierrat F, et al. (2010) Transcriptome and proteome analysis of Pinctada margaritifera calcifying mantle and shell: Focus on bio-mineralization. BMC Genomics.

40. Ky CL, Devaux D (2016) Polynesian pearls. Hatchery International 17: 20-21. 